\title{
AML-derived mesenchymal stem cells upregulate CTGF expression through the BMP pathway and induce K562-ADM fusiform transformation and chemoresistance
}

\author{
HAIYING LI ${ }^{1}, \mathrm{JUAN} \mathrm{LI}^{2}, \mathrm{JUAN} \mathrm{CHENG}^{3}, \mathrm{XUAN} \mathrm{CHEN}^{2}, \mathrm{LANXIA} \mathrm{ZHOU}^{2}$ and ZHAO $\mathrm{LI}^{2}$ \\ ${ }^{1}$ Department of Central Laboratory, The First Medical College of Lanzhou University, and Departments of ${ }^{2}$ Central Laboratory, \\ and ${ }^{3}$ Hematology, The First Hospital of Lanzhou University, Lanzhou University, Lanzhou, Gansu 730000, P.R. China
}

Received November 27, 2018; Accepted July 12, 2019

DOI: $10.3892 /$ or.2019.7237

\begin{abstract}
Bone marrow-derived mesenchymal stem cells (MSCs), are the basic cellular components that make up the bone marrow microenvironment (BMM). In acute myeloid leukemia (AML), the morphology and function of MSCs changes in accordance with the transformation of the BMM. Moreover, the transformation of MSCs into osteoblasts is determined through the bone morphogenetic protein (BMP) pathway, ultimately leading to an altered expression of the downstream adhesion molecule, connective tissue growth factor (CTGF). In this study, we aimed to explore the interaction of possible pathways in AML-derived mesenchymal stem cells (AML-MSCs) co-cultured with the K562 and K562-ADM cell lines. AML-MSCs were co-cultured with K562/K562-ADM cells, and the interactions between the cells were verified by morphological detection, peroxidase staining (POX), reverse transcription-quantitative polymerase chain reaction (RT-qPCR) and fluorescence in situ hybridization (FISH). The proliferation of K562/K562-ADM cells under co-culture conditions was detected by flow cytometry. The expression levels of BMP4 and CTGF were examined by RT-qPCR and western blot (WB) analysis. The detection of interleukin (IL)-6 and IL-32 was also determined by enzyme linked immunosorbent assay (ELISA). In the co-culture system, the K562-ADM cells underwent fusiform transformation. The occurrence of this transformation was associated with an increased expression of CTGF due to the dysregulation of the BMP pathway. The AML-MSCs promoted the proliferation of the K562-ADM cell, but inhibited that of the K562 cells.
\end{abstract}

Correspondence to: Dr Zhao Li, Department of Central Laboratory, The First Hospital of Lanzhou University, Lanzhou University, 1 Donggang West Road, Lanzhou, Gansu 730000, P.R. China E-mail: zhaoli@1zu.edu.cn

Key words: acute myeloid leukemia derived-mesenchymal stem cells, K562-ADM, bone morphogenetic protein, connective tissue growth factor, fusiform transformation
These findings were confirmed by changes in the expression of the soluble cytokines, IL- 6 and IL-32. On the whole, the findings of this study demonstrate that AML-MSCs regulate the expression of CTGF through the BMP pathway. In addition, they affect cytokine production, induce spindle-shaped transformation, and increase drug resistance in the K562-ADM cells. Thus, the morphological transformation through the BMP pathway provides us with a novel target with which to circumvent tumor occurrence, development, drug resistance, invasion and metastasis.

\section{Introduction}

Hematopoietic stem and progenitor cells (HSPCs) maintain blood production throughout an organism's lifespan through self-renewal and differentiation. In 1978, Schofield proposed that HSPCs in the bone marrow require anatomically defined regions to maintain function. These regions are composed of peripheral cells within a milieu of local extracellular stromal cells, termed the bone marrow microenvironment (BMM) or 'niche' (1). There is ample evidence to indicate that the transformation of the BMM acts directly or indirectly on leukemia cells, and can interfere with the development and progression of hematopoietic malignancies (2-6). However, contrasting reports have indicated that this interference by leukemia cells may even promote the development of leukemia within the BMM $(3,7,8)$. Regardless of the interaction, the role of the BMM is closely related to the occurrence, development, invasion and metastasis of leukemia.

Mesenchymal stem cells (MSCs), are a key component of the BMM, and are essential for regulating the number of HSPCs, as well as for maintaining normal hematopoietic function (9-11). Due to their central role, it is conceivable that they may influence the occurrence and development of leukemia. However, whether the effects of MSCs are positive $(12)$ or negative $(7,8,13)$ remains uncertain. Compared with healthy donor-derived MSCs (HD-MSCs), acute myeloid leukemia (AML)-derived MSCs (AML-MSCs) exhibit a distinct pattern of gene expression, cytokine production, immunophenotyped and cytogenetics $(14,15)$, with significant growth defects, insufficient osteogenic differentiation and accelerated cellular senescence $(4,16,17)$. These defects 
in AML-MSCs are closely related to DNA methylation, transcriptional gene expression (18) and chromosomal aberrations (19). Additionally, compared with HD-MSCs, the significant changes in cytokines, such as interleukin (IL)-6 and IL-32 induced by AML-MSCs has been shown to be associated with chemoresistance (20). Collectively, the BMM constructed by AML-MSCs can be considered distinct from that of HD-MSCs.

Bone morphogenetic proteins (BMPs) are a member of the transforming growth factor (TGF)- $\beta$ family, expressed primarily in the bone marrow stroma. They are the only known morphogenetic factors capable of inducing the differentiation of MSCs (21-24), and have been shown to play important roles in proliferation, hematopoiesis and the development of leukemia (25-27). There is increasing evidence linking BMPs to the transformation of the $\operatorname{BMM}(26,28,29)$ and this suggests a potential role of BMPs in leukemia. Along these lines, alterations in the BMP pathway resulting in MSC differentiation and the secretion of growth factors by MSCs has been shown to confer a growth advantage, as well as BMM transformation in AML (8). Moreover, BMP4-induced NANOG expression with increased stem cell-like characteristics has also been demonstrated in AML (30). In summary, BMP has shown to be critical for the self-renewal and differentiation of leukemia stem cells (LSCs) $(26,28)$, and is considered to be a unique factor in the development and progression of leukemia (27).

In 1991, Bradham et al found that connective tissue growth factor (CTGF) was isolated from human endothelial cells, and that it played an important role in cell adhesion, migration, proliferation and chemotaxis (31). CTGF mediates adhesion mainly by bridging extracellular matrix (ECM) components (including fibronectin, perlecan, vitronectin and decorin) to integral cell surface molecules, such as integrins and connexin $(32,33)$. CTGF protein induces the proliferation of MSCs, promotes the adhesion of leukemia cells to MSCs, and leads to the overexpression of genes involved in the cell cycle and ECM synthesis (34). More importantly, CTGF expression in MSCs may even be induced via $\mathrm{BMP} /$ Osterix/Runx2-mediated signaling in AML, and may enhance mouse leukemia implantation (8). Correspondingly, in a previous study, in co-culture experiments with HSPCs co-cultured with MSCs in which CTGF was knocked down, Smad 2/3-dependent signaling was found to be activated, resulting in blocked cell cycle progression and inhibited activation of HSPCs (35). BMP-2-induced signaling and osteoblast differentiation has been shown to be negatively regulated by CTGF (36). Therefore, the adhesion effect mediated by CTGF may be closely related to the BMP signaling pathway. Moreover, adhesion provides a protective BMM for leukemia cell survival (37-39), further leading to the presence of minimal residual disease, which becomes the source of genetic instability and relapse (40-42).

We hypothesized that the transformation of the BMM by AML-MSCs occurs through CTGF-mediated cell adhesion via the BMP pathway, and ultimately contributes to the development of chemoresistance. By performing co-culture experiments with AML-MSCs and either sensitive K562 or chemoresistant K562-ADM cells, in this study, we aimed to elucidate the mechanisms through which this occurs.

\section{Materials and methods}

AML patient-derived bone marrow donor samples. The bone marrow of patients with leukemia was provided by the Hematology Department of the First Hospital of Lanzhou University (January, 2015 to Novmber, 2018). All AML patients (aged 7-82 years, male/female ratio, 34/22) met the diagnostic criteria according to the World Health Organization (WHO) and the French-American-British (FAB) co-operative group (43). This study was approved by the Institutional Ethics Committee of the First Hospital of Lanzhou University and written informed consent was obtained from patients and/or their legal guardians. The collection and acquisition of MSCs was carried out according to the Declaration of Helsinki (44). HD-MSCs was purchased from Saiye Biotechnology Co. Ltd.

K562 and K562-ADM cells. The human ADM-resistant AML cell line, K562/ADM cells, and the non-resistant cell line, K562 cells, were both obtained from the Central Laboratory of the First Hospital of Lanzhou University (YB-H1580 and YB-H1581; Yu Bo Biotech Co.,Ltd.). The K562/ADM and K562 cells were grown in RPMI-1640 medium supplied with $10 \%$ fetal bovine serum (ZheJiang Tianhang Biotechnology Co., Ltd.) at $37^{\circ} \mathrm{C}$ in a humid atmosphere containing $5 \%$ carbon dioxide $\left(\mathrm{CO}_{2}\right)$. The cells were confirmed to have a confluence of $80-90 \%$ before being used in the experiments.

Culture of human AML-MSCs. Bone marrow aspirates $(2 \mathrm{ml})$ from patients with AML were added to a $25 \mathrm{~cm}^{2}$ culture flask (Corning, Inc.) containing DMEM/low glucose complete medium. The culture conditions were the same as those described above. After 7-10 days, the cultures were washed with PBS. The primary AML-MSCs were then obtained. The cultured AML-MSCs were cultured in osteogenic induction medium (500 $\mu \mathrm{l}$ vitamin C, $1 \mathrm{ml} \beta$-glycerophosphate and $10 \mu \mathrm{l}$ dexamethasone in $100 \mathrm{ml}$ DMEM) (45), followed by alkaline phosphatase assay and Alizarin Red staining to verify its ability to differentiate into osteoblasts.

For alkaline phosphatase staining, the cells were first fixed with $4 \%$ paraformaldehyde for 10-15 min and then washed with PBS. Subsequently, the alkaline phosphatase incubation solution (BeiJing Solarbio Technology Co., Ltd.) was added in dropwise manner on the cells followed by incubation for $20 \mathrm{~min}$ in an incubator $\left(37^{\circ} \mathrm{C}, 5 \% \mathrm{CO}_{2}\right)$, and washing with PBS. The cells were counterstained with nuclear solid red staining solution for $5 \mathrm{~min}$, and washed with PBS for microscopic examination (CKX41; Olympus).

For Alizarin Red staining, 0.2\% Alizarin Red (BeiJing Solarbio Technology Co., Ltd.) dye solution (0.1 g Alizarin red in $50 \mathrm{ml}$ PBS) was slowly added in a dropwise manner to the surface of the cells, followed by gentle shaking until the dye covered all the cells. The cells were then allowed to stand for 1-2 min, and then washed with PBS for microscopic examination (CKX41; Olympus).

Co-culture of AML-MSCs and K562 or K562-ADM cells. The primary AML-MSCs were sub-cultured by trypsinization, and third-generation cells were selected for testing. When cell growth reached between 80 and $90 \%$ confluence, the 
AML-MSCs were added to $5 \times 10^{5}$ cells $/ \mathrm{ml}$ of K562/K562-ADM cells for co-culture $\left(37^{\circ} \mathrm{C}, 5 \% \mathrm{CO}_{2}\right)$.

Morphological observations. The analysis of cell proliferation was carried out by MTT (Sigma) assay. The formazan was dissolved in DMSO and the OD value was measured at $490 \mathrm{~nm}$. The cell proliferation curve was plotted based on the OD value. The co-culture of AML-MSCs with either K562 or K562-ADM cells was performed for 24, 48 or $72 \mathrm{~h}$. Morphological observations were performed using an Olympus inverted biological microscope CKX41 (Olympus).

Peroxidase (POX) staining. Following co-culture, non-adherent cells were discarded. The remaining adherent cells were air-dried, and subsequently fixed with solution (3\% glutaraldehyde, $60 \%$ acetone solution) for $1 \mathrm{~min}$. Benzoyl benzidine $10 \mathrm{mg}+5 \mathrm{M}$ Tris-hydrochloride $40 \mathrm{ml}$ (pH 7.6) with $2 \%$ hydrogen peroxide at a 1:1 ratio was then added to fix the cells for $10 \mathrm{~min}$. After rinsing and drying, hematoxylin was used for counterstaining for $20 \mathrm{~min}$ and the cells were then washed with water. Finally, $0.5 \%$ ammonia was added to reverse blue coloration. Microscopic (CKX41; Olympus) examination was carried out after complete drying.

$R T$-qPCR. RT-qPCR was performed on adherent spindle cells at the end of the co-culture experiments. Cells were collected for RNA extraction once they entered the exponential growth phase, (approximately $5 \times 10^{7}$ cells $/ \mathrm{ml}$ ), as previously described (46). The quality and concentration of the RNA/total RNA were determined using a spectrophotometer (GE Nanovue Plus). In total, $<1 \mu \mathrm{g}$ of total RNA was used for reverse transcription. According to the manufacturer's instructions, cDNA was synthesized using the iScript gDNA Clear cDNA Synthesis kit (Bio-Rad). The concentration and qualitiy of all the obtained DNA samples were determined by UV spectroscopy as described above.

BCR-ABL expression was determined using the leukemia-associated fusion gene detection kit (Shanghai Yuanqi Biomedical Technology Co. Ltd.). The amplification conditions were as follows: $42^{\circ} \mathrm{C}, 30 \mathrm{~min} ; 94^{\circ} \mathrm{C}, 5 \mathrm{~min} ;\left(94^{\circ} \mathrm{C}\right.$, $\left.15 \mathrm{sec} ; 60^{\circ} \mathrm{C}, 60 \mathrm{sec}\right) 40$ cycles. The reaction system was $25 \mu 1$. The fluorescence signal was collected at the second step of the PCR cycle at $60^{\circ} \mathrm{C}$ and analyzed by the standard curve method in absolute quantitative detection. The standard reagent was a plasmid provided by the manufacturers that had been quantified and contained fixed copies of the BCR-ABL fusion gene (Yuanqi Biomedical Technology Co., Ltd.). The dilution was carried out with water. A calibration curve of the $\mathrm{Ct}$ values of the standard dilution series vs. the concentrations is calculated and used to determine the concentrations of the unknowns, based on their $\mathrm{Ct}$ values.

The detection of the BMP4 and CTGF genes was carried out by the relative quantification method. The sequences of the primers used were as follows (Takara): BMP4 forward, 5'-AGATCCACAGCACTGGTCTTGAGTA-3' and reverse, 5'-TCAGGGATGCTGCTGAGGTTA-3'; CTGF, forward, 5'-CTTGCGAAGCTGACCTGGAA-3' and reverse, 5'-AGC TCAAACTTGATAGGCTTGGAGA-3'; and $\beta$-actin forward, 5'-TGGCACCCAGCACAATGAA-3' and reverse, 5'-CTA AGTCATAGTCCGCCTAGAAGCA-3'. The cells were fluorescently labeled with iTaq Universal SYBR-Green Supermix (Bio-Rad). HD-MSCs alone served as the control group. The amplification conditions were as follows: $95^{\circ} \mathrm{C}$, $5 \mathrm{~min} ;\left(95^{\circ} \mathrm{C}, 15 \mathrm{sec} ; 60^{\circ} \mathrm{C}, 60 \mathrm{sec}\right) 40$ cycles; $95^{\circ} \mathrm{C}, 5 \mathrm{sec}$; $65^{\circ} \mathrm{C}, 60 \mathrm{sec} ; 40^{\circ} \mathrm{C}, 30 \mathrm{sec}$. The reaction system was $20 \mu 1$. Detection was performed using a Roche LightCycler ${ }^{\circledR} 480$ Fluorescence PCR detector (Roche). The obtained data is the $\mathrm{Ct}$ value. The $\mathrm{Ct}$ values of the repeat sample wells were averaged and calculated by the $2^{-\Delta \Delta C q}$ method (the reference gene was $\beta$-actin) (47).

Western blot analysis. The cells were lysed with lysis buffer (1\% SDS, $10 \mathrm{~mm}$ Tris-HCl, pH 7.6, $20 \mathrm{~g} / \mathrm{ml}$ aprotinin, $20 \mathrm{~g} / \mathrm{ml}$ leupeptin and $1 \mathrm{~mm}$ AEBSF). Protein concentrations were determined using the Bradford method (48). Protein $(20 \mu \mathrm{g})$ was separated on $12 \%$ SDS-PAGE gels and transferred onto PVDF membranes (Merck Millipore). After blocking with 10\% skim milk, the membranes were incubated with the primary antibodies (anti-CTGF antibody, 1:1,000, cat. no. ab6992, Abcam; anti-phospho-Smad1/5 antibody, 1:1,000, cat. no. 9516, Cell Signaling Technology) at $4^{\circ} \mathrm{C}$ overnight. After washing 3 times with triethanolamine buffer solution (Sangon Biotech Co., Ltd.), the membranes were incubated with goat anti-rabbit IgG horseradish peroxidase-conjugated secondary antibodies (cat. no. 31460; Invitrogen; Thermo Fisher Scientific) (1:200 dilution in 5\% skim milk) at room temperature for $1 \mathrm{~h}$. The signals were examined with the ECL kit (Elabscience Biotechnology Co., Ltd.), using anti- $\beta$-actin antibody (1:1,000, cat. no. 4970; Cell Signaling Technology) as an internal control. Protein gray value detection was performed using ImageJ software (National Institutes of Health).

Fluorescence in situ hybridization (FISH). The co-cultured cells as described above were placed onto glass slides. The tightly adherent cells were washed with PBS after $24 \mathrm{~h}$. The slides were placed in hypotonic $0.075 \mathrm{M}$ potassium chloride solution at $37^{\circ} \mathrm{C}$ for $20 \mathrm{~min}$, then placed 3 times in fixative (methanol:glacial acetic acid, 3:1) for 1 min each time. The slides were then placed on a roaster (Tianjin Tianli Aviation Electro-Mechanical Co., Ltd.) at $56^{\circ} \mathrm{C}$ for $10-20 \mathrm{~min}$, then immersed in 2X SSC buffer (sodium chloride:sodium citrate, 2:1; $\mathrm{pH} 7.0 \pm 0.2$ ) twice for $5 \mathrm{~min}$ each time. They were then placed in $0.1 \mathrm{M} \mathrm{HCl}$ for $10 \mathrm{~min}$, and again immersed in 2X SSC buffer twice for 2 min each. Pepsin was added dropwise onto the slides followed by incubation at $37^{\circ} \mathrm{C}$ for $11 \mathrm{~min}$. They were then washed twice in 2X SSC buffer for 5 min each. Finally, the slides were immersed in formaldehyde fixative $\left(1 \mathrm{ml}\right.$ formaldehyde and $0.18 \mathrm{~g} \mathrm{MgCl}_{2} \cdot 6 \mathrm{H}_{2} \mathrm{O}$ in $39 \mathrm{ml}$ PBS) for $10 \mathrm{~min}$, and then sequentially dehydrated through a gradient of ethanol concentrations (70,85 and 100\%) over a period of $3 \mathrm{~min}$ at room temperature.

The BCR-ABL fluorescence probe were prepared (Jinpujia Pharmaceutical Technology Co., Ltd.) in a dark room for in situ hybridization $\left(75-80^{\circ} \mathrm{C}, 5 \mathrm{~min} ; 42^{\circ} \mathrm{C}\right.$, overnight; In situ hybridization apparatus, IRIS International Inc.).

The slides for in situ hybridization were placed into two different $2 \mathrm{X} \mathrm{SSC}$ buffers $\left(46^{\circ} \mathrm{C}\right.$, water bath for $\left.30 \mathrm{~min}\right)$ shaken for 1-3 sec, rinsed for $15 \mathrm{~min}$, and then rinsed in $0.1 \%$ NP-40/2X SSC buffer for $15 \mathrm{~min}$. Finally, the slides were soaked in $70 \%$ ethanol for $3 \mathrm{~min}$ at room temperature. 

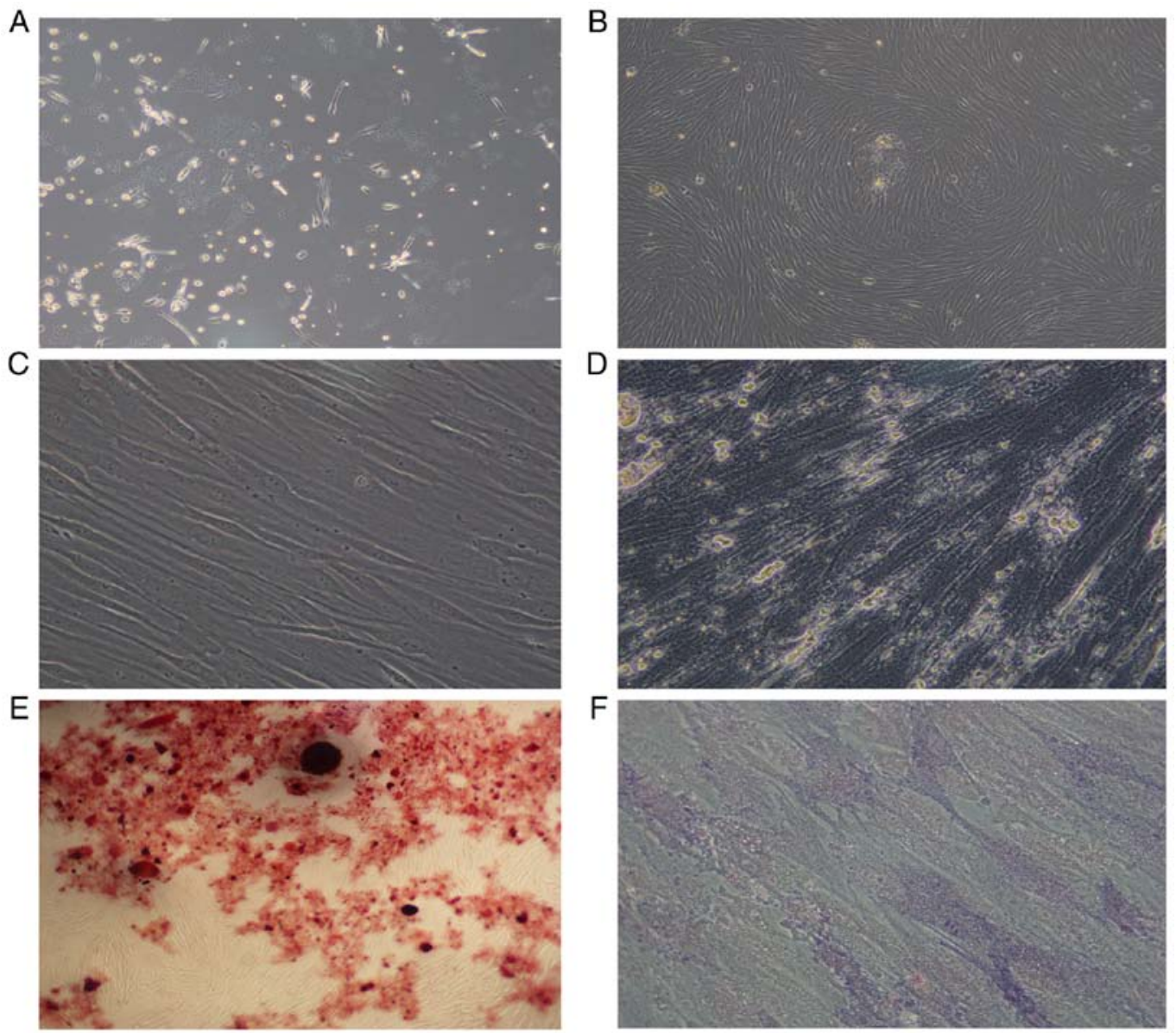

Figure 1. Morphology of AML-MSCs. (A) AML-MSCs cultured after 7-10 days. (B) AML-MSCs cultured after 14-21 days. (C) Subculture of AML-MSCs. (D) AML-MSCs osteogenic induction culture for 14 days. (E) AML-MSCs stained with alizarin red. (F) AML-MSCs stained with alkaline phosphatase. Magnification was as follows: (A) x10; (B) x4; (C) x40; (D) x40; (E) x4; (F) x40. AML-MSCs, acute myeloid leukemia derived-mesenchymal stem cells.

A total of $15 \mu$ l DAPI were added to the slides to stain the cell nuclei after which they were observed under a fluorescence microscope (Olympus) after 10-20 min of incubation at room temperature.

Detection of IL-6 and IL-32 in the supernatant by enzyme linked immunosorbent assay (ELISA). Supernatants from co-culture experiments was collected and the detection of human IL-6 and IL-32 levels by ELISA was performed according to manufacturer's protocol (Shanghai JiangLai Biotechnology Co., Ltd.).

Cell cycle detection. Cell suspensions containing approximately $2 \times 10^{5}$ to $1 \times 10^{6}$ cells from co-cultures at 24,48 and $72 \mathrm{~h}$ were subjected to cell cycle analysis according to the manufacturer's protocol (Cell Cycle Staining kit, Hangzhou Lianke Biotechnology Co., Ltd.). Detection was performed on a BD FACS Verse flow cytometer (BD Bioscienses).

Statistical analysis. Statistical analyses were performed using GraphPad Prism 7.0 software (GraphPad Software). Multigroup comparisons were carried out by ANOVA analysis. The Bonferroni correction was performed as a post hoc test for the data that were subjected to two-way ANOVA analysis. P-values $<0.05$ were considered top indicate statistically significant differences.

\section{Results}

Morphology of AML-MSCs. The AML-MSCs were found to be adherent cells, with a spindle-like shaped and to be irregularly arranged (Fig. 1A). After 14-21 days, the number of adherent cells increased significantly, which grew in parallel or in a spiral-like manner (Fig. 1B). The growth rate and size of the sub-cultured AML-MSCs were also greater than that of the primary cells (Fig. 1C). After 14 days of culture with an osteogenic inducer (dexamethasone, vitamin $\mathrm{C}, \beta$-sodium glycerophosphate), the cytoplasm of the cells was filled with granules, and calcium deposition was observed between the cells (Fig. 1D), and red nodules were observed following staining with Alizarin Red (Fig. 1E). Alkaline phosphatase staining revealed a large amount of purple-brown sediment in the extracellular matrix (Fig. 1F). Thus, it was found that the AML-MSCs conformed to the standards of the International Society for Cell Therapy (49).

AML-MSCs promote the fusiform transformation of K562-ADM cells. We observed a unique morphologic alteration in the drug-resistant K562-ADM cells that was associated with the enhanced growth advantage. There were two layers of cells in the culture plate. The bottom layer contained AML-MSCs and the upper layer suspended K562 or K562-ADM cells. After 24 h, the K562-ADM cells exhibited 

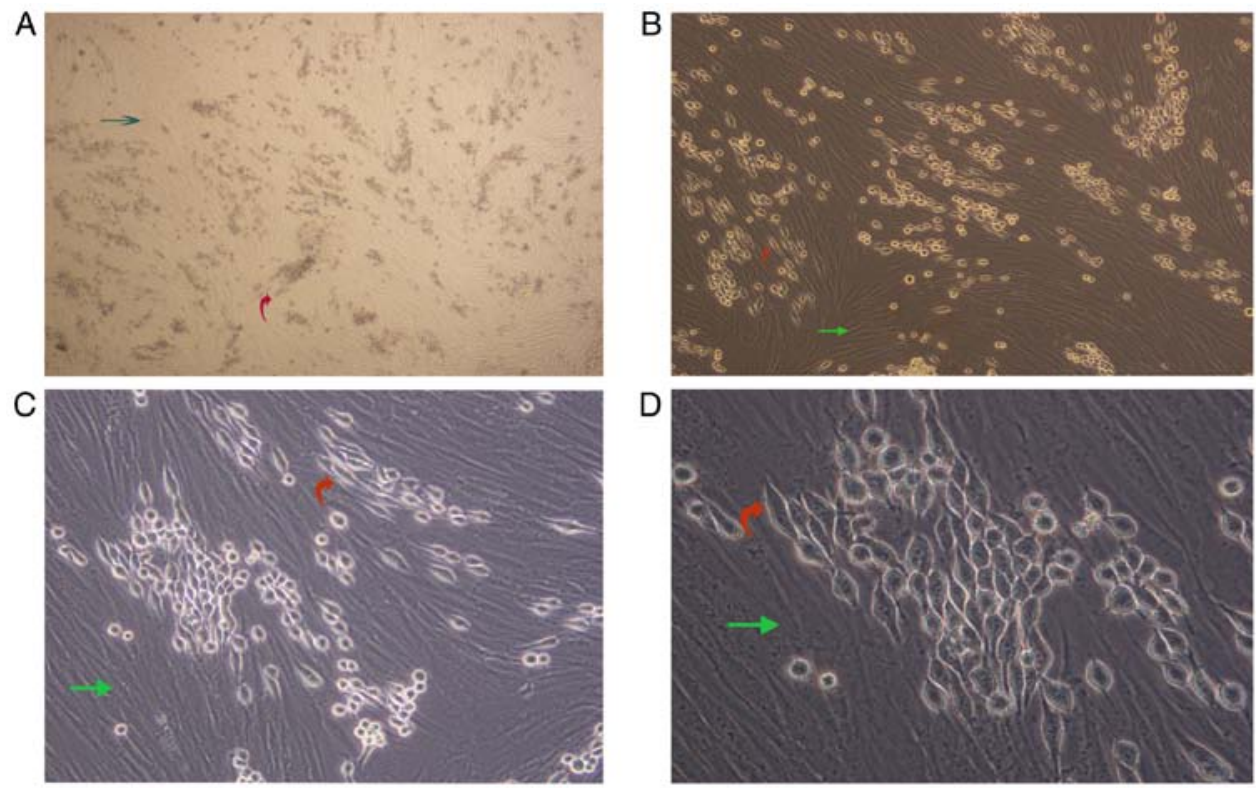

Figure 2. (A-D) Morphological changes observed following co-culture of AML-MSCs with K562-ADM cells. Bottom layer, AML-MSCs (green arrows); upper layer, K562-ADM cells, including spindle-shaped transformed cells and original spherical cells (red arrows). Magnification was as follows: (A) x4; (B) $x 10$; (C) x20; (D) x40. AML-MSCs, acute myeloid leukemia derived-mesenchymal stem cells.

A

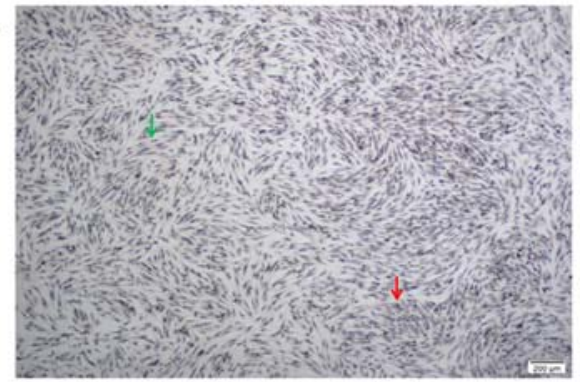

C

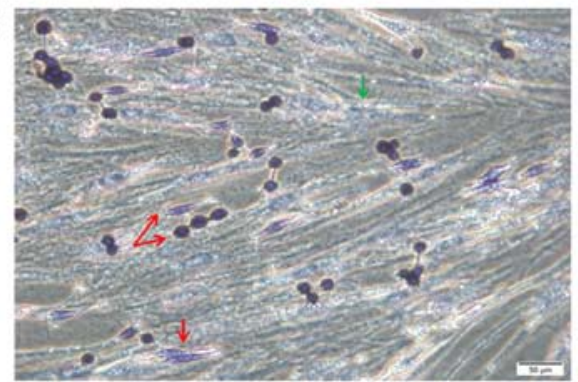

B

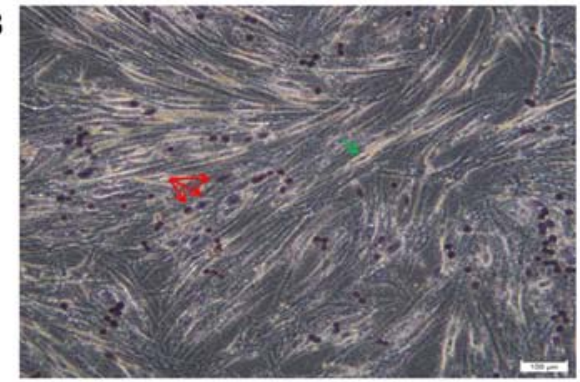

D

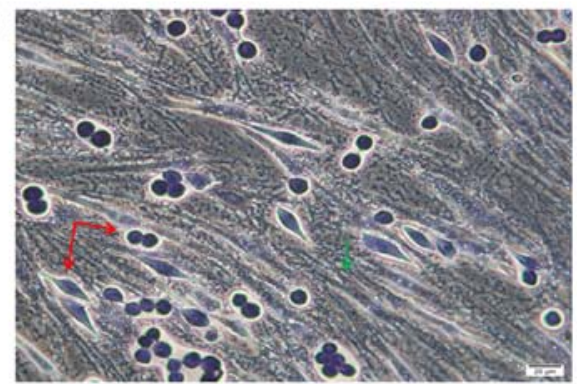

Figure 3. (A-D) POX staining. The bottom spindle-shaped cells were AML-MSCs negative for POX staining (green arrows). The superficially adherent K562-ADM cells had two forms, one was a normal spherical cell, and the other was a spindle-shaped cell. All cells were stained positive for POX (red arrows). Magnification was as follows: (A) x4; (B) x10; (C) x20; (D) x40. AML-MSCs, acute myeloid leukemia derived-mesenchymal stem cells.

a large amount of adhesion, which was accompanied by fusiform transformation. Moreover, the transformed spindle cells were larger in the middle, and the volume was smaller than that of the AML-MSCs. The size of the transformed spindle cells was approximately one-third that of the AML-MSCs, and the transparency of the transformed spindle cells was better. The contents are clearly visible (Fig. 2).

POX staining revealed that the cells were of two origins. The bottom spindle cells were AML-MSCs and were negative for POX, and larger. The upper adherent cells had two forms, the cells were small and both were granulocyte sources, and were positive or strongly positive for POX (Fig. 3).
Absolute quantitative detection by RT-qPCR demonstrated significant differences in the expression levels of BCR-ABL between the controls (AML-MSCs) and the experimental groups (K562 or K562-ADM-derived co-cultured cells) $(\mathrm{P}<0.001)$, confirming two different populations of cells (Fig. 4). Compared with the K562 co-culture group, the expression level of BCR-ABL in the K562-ADM co-culture group was significantly increased $(\mathrm{P}<0.001$; Fig. 4). This may be related to the significant increase in adherent and spindle-shaped transformed cells in the K562-ADM co-culture group (the K562 co-culture group had fewer adherent cells and almost no fusiform transformation; Figs. 2 and 3). 


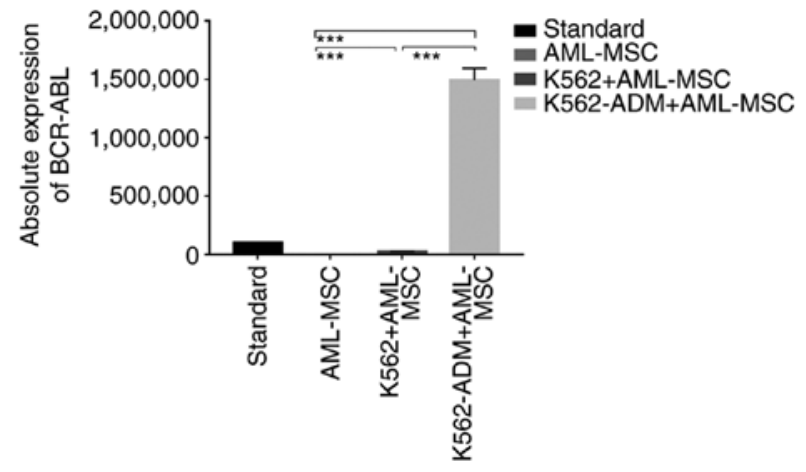

Figure 4. Absolute quantitative detection of BCR-ABL. RT-PCR was performed on all adherent cells (AML-MSCs and spindle-transformed cells). Since AML-MSCs did not express BCR-ABL, it was confirmed that the adherent and fusiform transformed cells were K562-ADM cells. ${ }^{* * *} \mathrm{P}<0.001$. AML-MSCs, acute myeloid leukemia derived-mesenchymal stem cells.

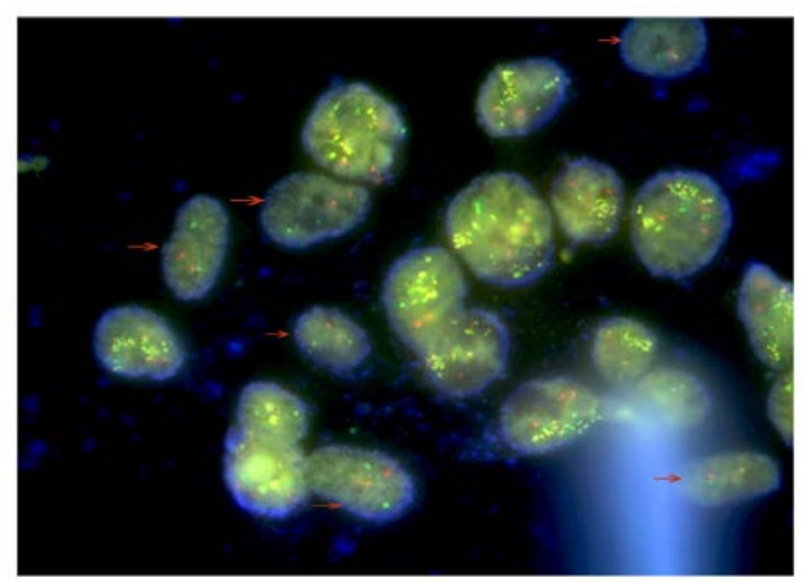

Figure 5. FISH analysis. FISH assay revealed that there were 2 types of cells in the visible field. The cells indicated by the arrows are AML-MSCs with a negative BCR/ABL expression. Other cells are the K562-ADM cells which were positive for BCR/ABL expression (49). FISH, fluorescence in situ hybridization; AML-MSCs, acute myeloid leukemia derived-mesenchymal stem cells.

The presence of two different cell types was furthermore confirmed by FISH, with AML-MSCs negative for BCR-ABL indicated by arrows (Fig. 5). Due to the polyploid genetic characteristics of the K562 or K562-ADM cell lines, and the fact that there are multiple sets of gene loci fusions, the results shown in Fig. 5 are in accordance with the results presented in the study by Gribble et al (50).

These above-mentioned experimental results confirm the morphological changes of the K562-ADM cells under co-culture conditions with AML-MSCs. Moreover, AML-MSCs induced the transformation of K562-ADM cells from a circular suspension cell to an adherent spindle cell with a positive BCR/ABL expression.

Changes in BMP4 and CTGF gene expression. Compared with the HD-MSCs, the BMP4 levels in the AML-MSCs decreased significantly $(\mathrm{P}<0.001$; Fig. 6A). Moreover, the AML-MSCs co-cultured with the K562-ADM cells exhibited lower BMP4 expression levels compared to those co-cultured with the K562 cells in a time dependent manner. Conversely, the AML-MSCs co-cultured with the K562 cells

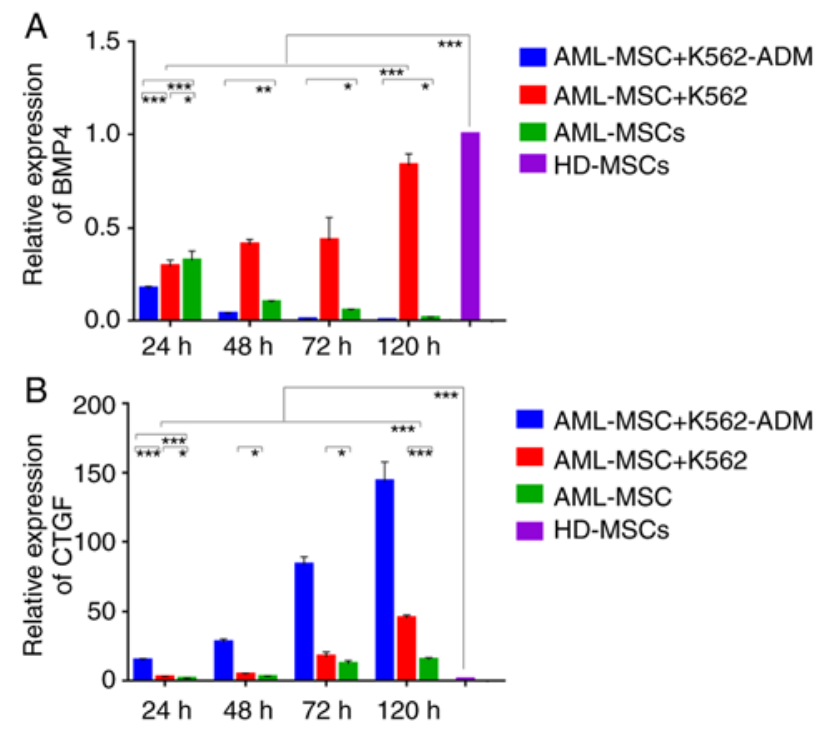

Figure 6. Relative quantitative detection of BMP4 and CTGF expression. (A) A gradual decrease was observed in BMP4 expression in AML-MSCs co-cultured with K562-ADM cells compared with the AML-MSCs cultured alone. BMP4 expression was increased in AML-MSCs co-cultured with K562 ( ${ }^{*} \mathrm{P}<0.05,{ }^{* *} \mathrm{P}<0.01$ and $\left.{ }^{* * *} \mathrm{P}<0.001\right)$. (B) An increase in CTGF expression was observed in the AML-MSCs co-cultured with either K562-ADM or K562 cells compared to the AML-MSCs cultured alone $\left({ }^{*} \mathrm{P}<0.05,{ }^{* *} \mathrm{P}<0.01\right.$ and $\left.{ }^{* * *} \mathrm{P}<0.001\right)$. AML-MSCs, acute myeloid leukemia derived-mesenchymal stem cells; HD-MSCs, healthy donor derived-mesenchymal stem cells. Based on the analysis of ANOVA and a post hoc test, unlabeled comparisons between groups were ${ }^{* * *} \mathrm{P}<0.001$.

exhibited a significant increase in BMP4 expression with time $(\mathrm{P}<0.001$; Fig. 6A).

Compared with the HD-MSCs, CTGF expression in the AML-MSCs was upregulated significantly $(\mathrm{P}<0.001$; Fig. 6B), and was found to be increased even further following co-culture with the K562-ADM cells compared with the K562 cells $(\mathrm{P}<0.001$; (Fig. 6B). Both co-cultures exhibited a time dependent increase in CTGF expression $(\mathrm{P}<0.001$; Fig. 6B) and this was consistent with the morphological observations.

Detection of $p$-Smad $1 / 5$ and CTGF protein expression. The protein expression of CTGF was confirmed to be present in the co-cultured cells compared to the HD-MSCs, and was greater in the AML-MSCs with co-cultured with the AML-MSCs co-cultured with K562-ADM cells ( $<<0.001$; Fig. 7A and D). This was likewise consistent with the morphological observations. Conversely, $\mathrm{p}$-Smad $1 / 5$ expression was found to be lower in the K562-ADM co-culture group compared to the K562 co-culture group $(\mathrm{P}<0.001$; Fig. 7B and $\mathrm{E})$.

Changes in the levels of soluble cytokines. The results of ELISA revealed that the IL-6 levels gradually increased over time in the AML-MSC culture group. The IL-6 levels significantly increased after the AML-MSCs were co-cultured with the K562-ADM cells ( $\mathrm{P}<0.001$; Fig. 8). However, IL-6 production by the K562 cells co-cultured with the AML-MSCs was lower than that by the AML-MSCs cultured alone $(\mathrm{P}<0.05$; Fig. 8). Although these levels increased slightly with time, they remained low, and were much lower than those in the K562-ADM co-culture group ( $\mathrm{P}<0.001$; Fig. 8). 


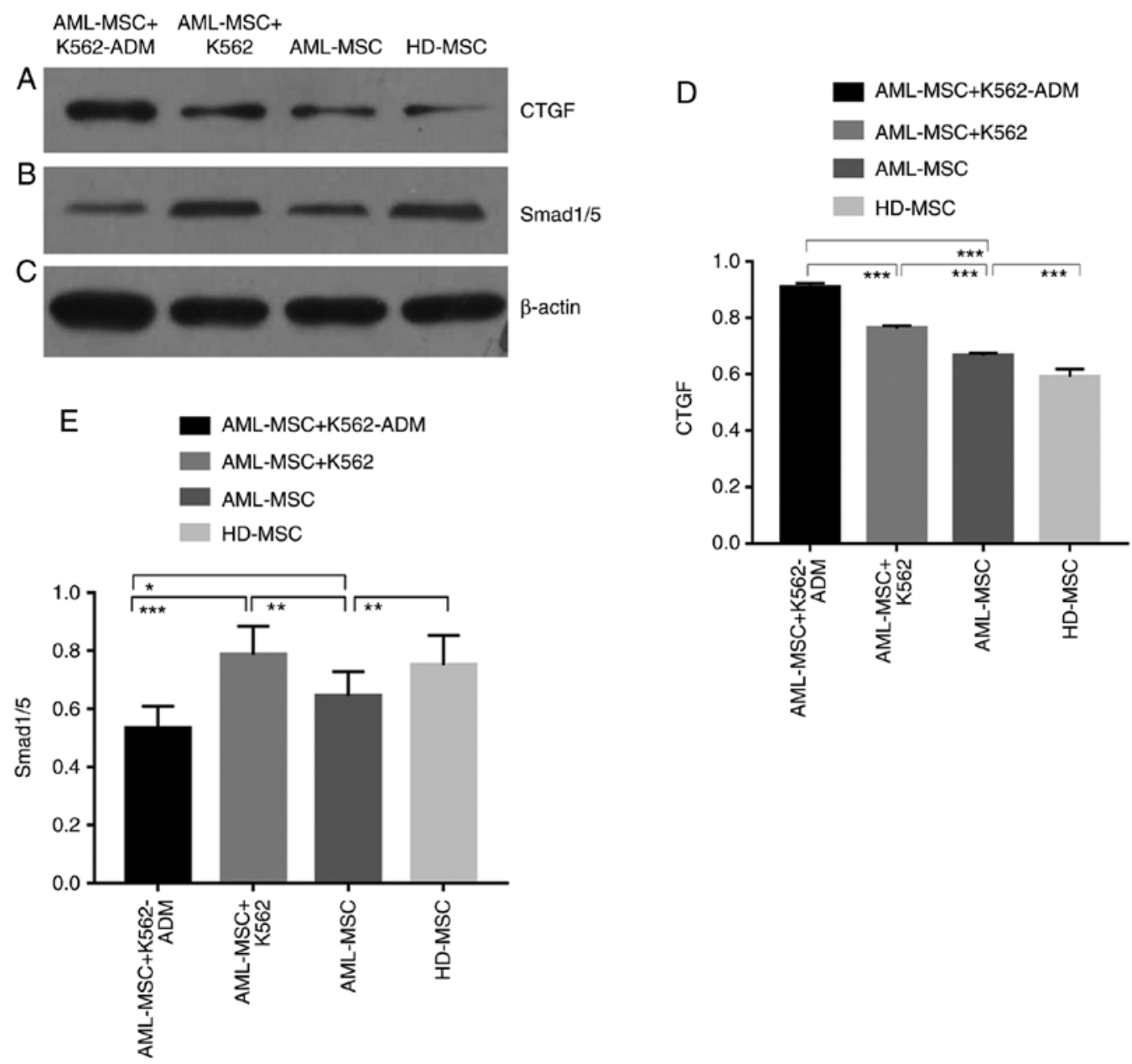

Figure 7. Western blot analysis detection and analysis. (A) Western blot demonstrating CTGF protein expression. (B) Western blot demonstrating phosphorylated smad1/5 protein expression. (C) Western blot demonstrating $\beta$-actin protein expression. (D) CTGF protein expression was significantly increased in the co-culture group compared with the culture group alone. The expression of AML-MSCs was higher than that of HD-MSCs $\left.{ }^{* * * *} \mathrm{P}<0.001\right)$. (E) The expression of phosphorylated protein smad1/5 was significantly increased in the K562 co-culture group, and significantly decreased in the K562-ADM co-culture group. The expression of AML-MSCs was lower than that of the HD-MSCs group $\left({ }^{*} \mathrm{P}<0.05,{ }^{* *} \mathrm{P}<0.01\right.$ and $\left.{ }^{* * *} \mathrm{P}<0.001\right)$. AML-MSCs, acute myeloid leukemia derived-mesenchymal stem cells; HD-MSCs, healthy donor derived-mesenchymal stem cells.

Similarly, the IL-32 levels in the K562-ADM co-culture group were significantly higher compared with the single culture group and the K562 co-culture group $(\mathrm{P}<0.001$; Fig. 9). However, when the co-culture time exceeded $48 \mathrm{~h}$, the IL-32 levels decreased slightly in the K562 co-culture group compared to the AML-MSCs cultured alone ( $\mathrm{P}<0.001$; Fig. 9).

Changes in the cell cycle. At $24 \mathrm{~h}$, the AML-MSCs co-cultured with the K562-ADM cells exhibited a decreased percentage in the population of cells in the in $\mathrm{G} 2+\mathrm{S}$ phases compared with the K562-ADM cells cultured alone; however, this percentage gradually increased, with the percentage of cells in the $\mathrm{G} 2+\mathrm{S}$ phase exceeding that of the individual culture group at $72 \mathrm{~h}$ (Fig. 10A). The results also revealed the increased proliferation of K562-ADM cells with time spent in co-culture with the AML-MSCs, whereas the opposite trend was observed in the K562-ADM cells cultured alone ( $\mathrm{P}<0.001$; Fig. 10C). The cell cycle analysis results of the K562 cells co-cultured with the AML-MSCs were consistent with those of the K562 cells cultured alone, and cell proliferation was inhibited over time $(\mathrm{P}<0.01$; Fig. 10D). Therefore, AML-MSCs exert a promoting effect on the proliferation of K562-ADM cells, but exert an inhibitory effect on the proliferation of K562 cells $(\mathrm{P}<0.001$; Fig. 10E).

\section{Discussion}

In our study, we observed a unique morphological alteration in the drug-resistant K562-ADM cells. The results of this study found that a fusiform transformation of the K562-ADM cells occurred following co-culture with AML-MSCs (Figs. 2-5). Since this change is necessarily accompanied by the adhesion of the two co-cultured cells, we further examined the levels of CTGF and its related pathway, BMP. Combined with the results of cytokine and cell cycle analyses, we found that the AML-MSCs utilize the BMP pathway to induce the upregulation of CTGF expression and cytokine secretion (Figs. 6-9), ultimately promoting the proliferation of K562-ADM cells (Fig. 10). However, due to the differential expression of BMP4, CTGF and cytokines, these morphological changes were not observed in the non-resistant K562 cells. The AML-MSCs significantly inhibited cell proliferation when co-cultured with the K562 cells (Fig. 10E). This further confirmed the existence of an interaction between the BMM and AML cells. 


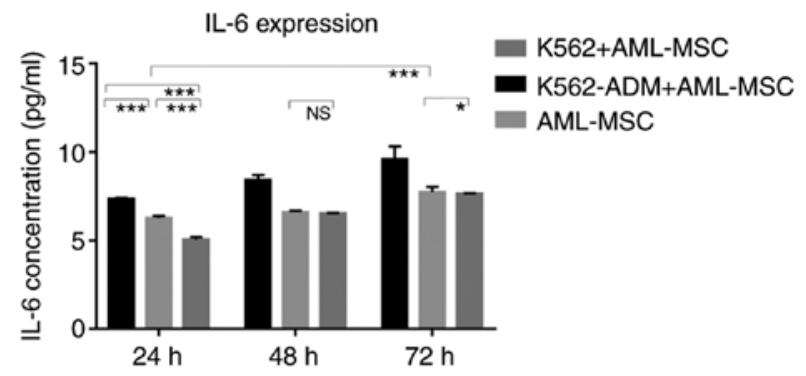

Figure 8. ELISA detection of IL-6 levels. A time-dependent increase in the expression of IL- 6 in both the control and experimental groups was observed. The expression of IL-6 was significantly increased in the AML-MSCs co-cultured with K562-ADM cells compared with the AML-MSCs cultured alone $\left({ }^{* * *} \mathrm{P}<0.001\right)$. A decreased expression of IL-6 was observed in the AML-MSCs co-cultured with K562 cells compared with the AML-MSCs cultured alone $\left({ }^{*} \mathrm{P}<0.05\right.$ and $\left.{ }^{* * *} \mathrm{P}<0.001\right)$. AML-MSCs, acute myeloid leukemia derived-mesenchymal stem cells. Unlabeled comparisons between groups were ${ }^{* * *} \mathrm{P}<0.001$.

Recently, there has been widespread debate over the role of MSCs in tumor cells. Some studies have suggested that leukemia-derived MSCs have a normal differentiation, adhesion, expression and survival, and the ability to support hematopoiesis $(13,19,51-54)$. Moreover, MSCs may inhibit the progression of leukemia cells (13). This is in stark contrast to the findings of other studies showing that an abnormal differentiation, defective hematopoietic capacity, a reduced expression of adhesion molecules, and increased an apoptosis occur in leukemia-derived MSCs $(4,14,55-58)$, within the tumor microenvironment to promote the growth of leukemia cells.

Nevertheless, finding an exact mechanism of tumor resistance remains to be discerned. Mohammadi et al found that AML cells co-cultured with MSCs and osteoblasts became more resistant to drug-induced apoptosis (59). Related studies have also confirmed that MSCs support AML cells survival and bone marrow transplantation, thereby promoting drug resistance (60-62). Moreover, the physical contact or adhesion of leukemia cells to cellular components in the BMM has been found to mediate chemoresistance (60), and K562 cells specifically have been shown to exhibit cell adhesion and resistance to apoptosis when exposed to BCR/ABL inhibitors AG957 and STI-571 (63). Furthermore, related factors that cause cell adhesion promote the long-term protection of leukemia stem cells (LSCs) by the BMM, which is an important cause of clonal proliferation and disease recurrence $(41,42)$. In this study, adhesion occurred prior to this morphological transformation. Therefore, we hypothesized that the adhesion of K562-ADM cells mediated by AML-MSCs is the cause of fusiform transformation and drug resistance.

As a key factor in adhesion, CTGF can induce the formation of spherical cell aggregates, causing attached cells to exhibit morphological changes, from spherical to flat or elongated shapes (64). By examining CTGF expression at the gene and protein levels in AML-MSCs, we observed a significant upregulation following co-culture with the K562-ADM cells (Figs. 6 and 7) vs. the non-resistant K562 cells. This was consistent with the fusiform transformation. The continuous overexpression of CTGF negatively regulates

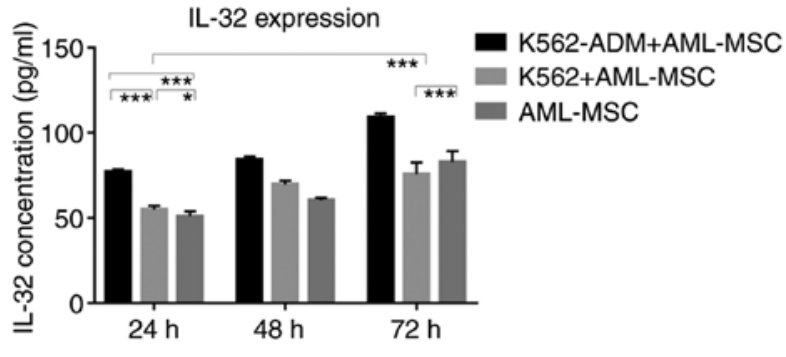

Figure 9. ELISA detection of IL-32 levels. A time-dependent increase in the expression of IL-32 in both the control and experimental groups was observed. The expression of IL-32 was significantly increased in the AML-MSCs co-cultured with K562-ADM cells compared with the AML-MSCs cultured alone $\left({ }^{* * *} \mathrm{P}<0.001\right)$. An increased expression of IL-32 was observed in the early stages of the AML-MSC co-culture with K562 cells compared with the AML-MSCs cultured alone $\left({ }^{*} \mathrm{P}<0.05\right.$ and $\left.{ }^{* * *} \mathrm{P}<0.001\right)$, although this gradually decreased after $48 \mathrm{~h}\left({ }^{* * *} \mathrm{P}<0.001\right)$. Unlabeled comparisons between groups were ***** $\mathrm{P}<0.001$.

the BMP-2-induced signaling pathway and osteoblast differentiation, resulting in decreased protein levels of phosphorylated Smad 1/5/8 (36). The adhesion of MSCs has previously been shown to be primarily mediated through the ERK and BMP signal pathways (65). This is consistent with the results of the decreased BMP4 and Smad1/5 protein levels found in this study (Figs. 6 and 7) and lends further support to the role of CTGF in the BMP pathway in the development of drug resistance.

In this study, we only tested the classical BMP4 protein of the BMP family. Further research is required to assess the role of additional members of the BMP family as regards CTGF expression and the BMP pathway. Future investigations may additionally shed light onto the development and chemoresistance of AML in response to drug targeting the BMP pathway.

Soluble factors involved in stem cell renewal are the primary targets within the BMM, and MSCs may antagonize chemotherapy within this microenvironment by acting on the cytokine network $(58,66)$. As a core player, IL-6 has shown to be capable of driving the initiation, growth and metastasis of tumors (67-69). Simultaneously, IL-6 is secreted by MSCs, which activates signal transduction and transcriptional activator 3 (STAT3), further leading to activation of TGF- $\beta$ signaling, thereby affecting the growth, proliferation and cytoprotection of stem and progenitor cells (70). In combination with BMPs present in serum, IL-6 may additionally function to enhance the self-renewal and affect the pluripotency of embryonic stem cells (71). IL-6 and its downstream signaling molecules are responsible for multidrug resistance (72). Similarly, changes in IL-32 levels can alter the chemical protective effects of cells on cytarabine-induced apoptosis (20). In this study, our co-culture experiments further implicated the role of IL- 6 and IL-32 in the development of chemoresistance as mediated by CTGF and the BMP pathway (Figs. 6, 8 and 9), which further indicates that the BMP pathway and CTGF may alter the BMM and participate in tumor resistance.

In conclusion, the findings of this study suggest that the BMM, which is largely composed of MSCs undergo various changes that confer drug resistance. These changes occur at the genetic and transcriptional level involving changes in cytokines, adhesion, and immunity $(18,19,52,73,74)$. Precipitating 
A
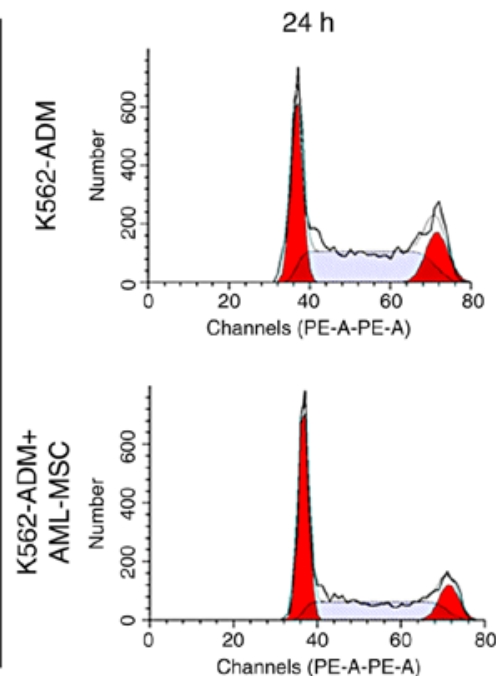

B

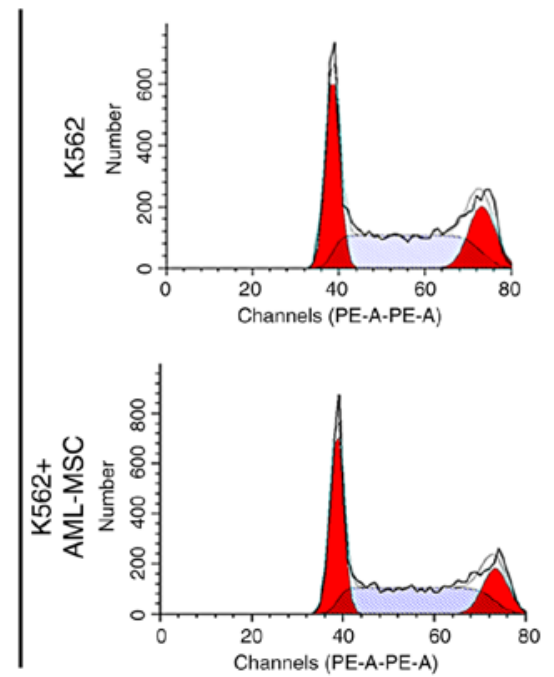

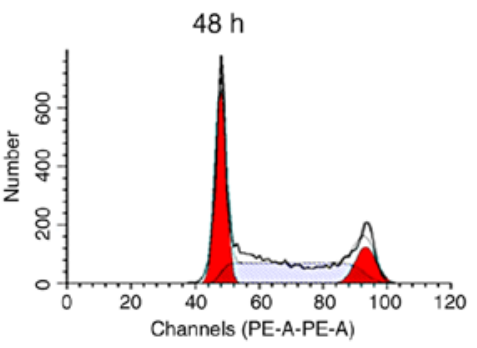
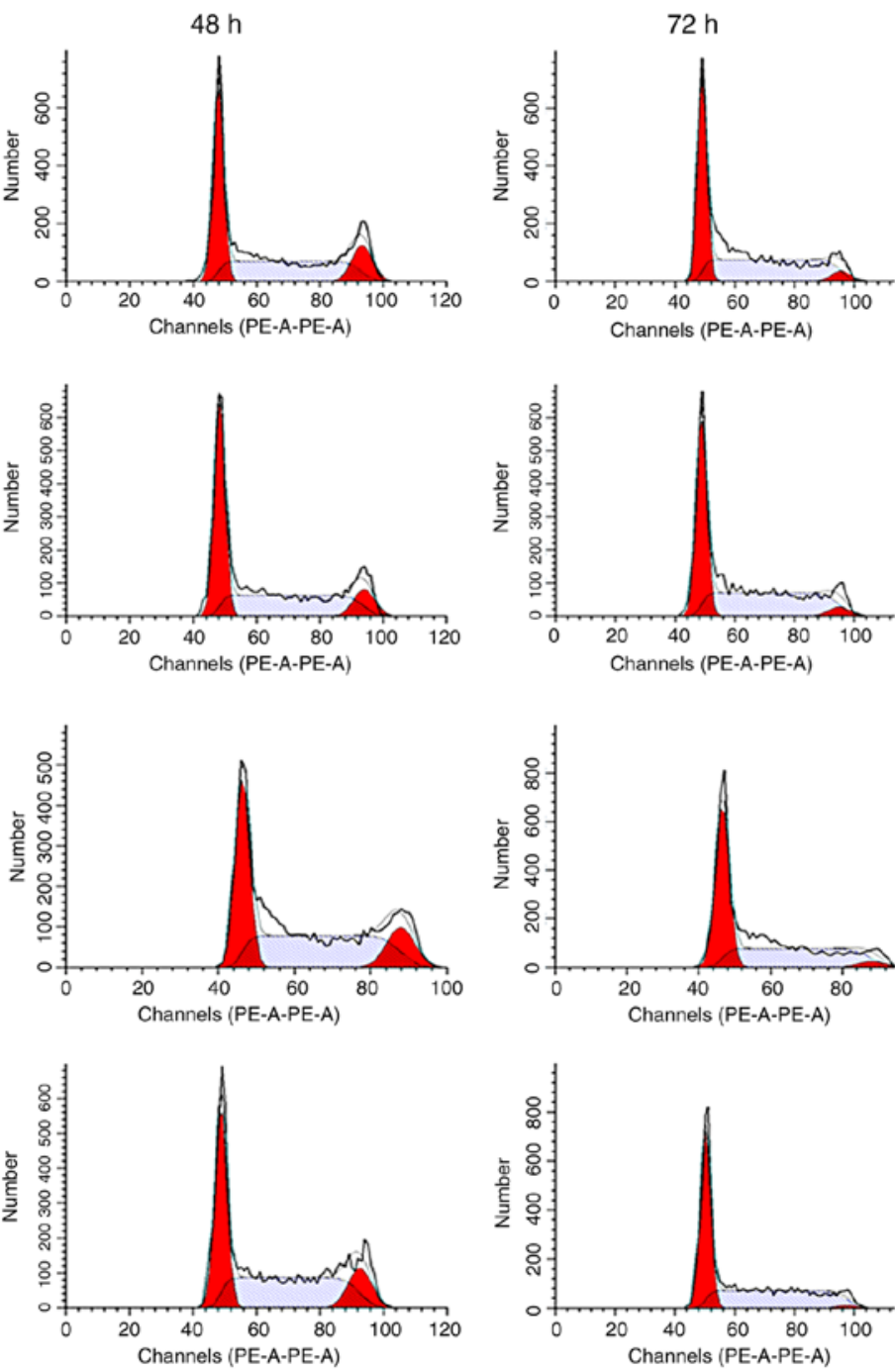
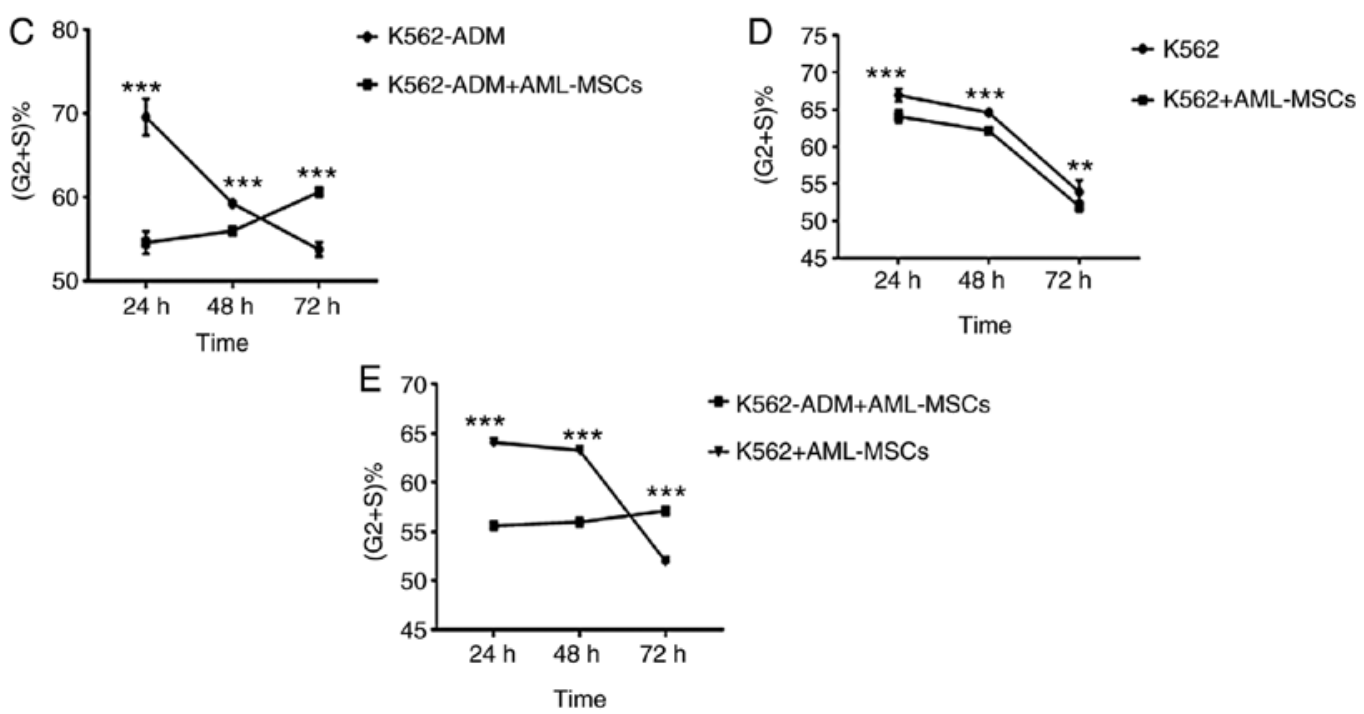

Figure 10. Cell cycle detection. (A) Cell cycle analysis: K562-ADM cells vs. K562-ADM and AML-MSC co-culture group. (B) Cell cycle analysis: K562 cells vs. K562 and AML-MSC co-culture group. (C) K562-ADM cells exhibited an increased proliferation following co-culture with AML-MSCs $\left({ }^{* * *} \mathrm{P}<0.001\right)$. (D) K562 cells exhibited an inhibition of cell proliferation following co-culture with AML-MSCs ${ }^{* * *} \mathrm{P}<0.01$ and $\left.{ }^{* * * *} \mathrm{P}<0.001\right)$. (E) Comparison of K562-ADM+AML-MSCs vs. K562+AML-MSCs ( $\left.{ }^{* * *} \mathrm{P}<0.001\right)$. AML-MSCs, acute myeloid leukemia derived-mesenchymal stem cells.

factors, include those from the environment, radiation and chemotherapy (75), as well as from leukemia cells themselves (8). The extent to which these changes are observed depends on a combination of factors, which cumulatively contributes to a heterogenous leukemic microenvironment and plausibly confer chemoresistance. 
The findings of this study suggest that changes in AML-MSCs in the BMM result in the dysregulation of the BMP pathway. This dysregulation further modifies the secretion and expression of CTGF, which induces morphological changes in K562-ADM cells. This shift may be the result of an increased CTGF expression or the conversion of K562-ADM cells to leukemic stem cells. Moreover, IL-6 and IL-32, which are known to promote the proliferation of HSPCs, were elevated in the K562-ADM co-cultured with AML-MSCs. Therefore, this transformation may be key for the recurrence of leukemia, and its inhibition may be essential for eradicating minimal residual disease. Lastly, this study provides further support for the role of cell adhesion in drug resistance, and demonstrated the importance of the BMP pathway in the BMM, providing a novel therapeutic target for the treatment of leukemia and prevention of its recurrence.

\section{Acknowledgements}

Not applicable.

\section{Funding}

This study was supported by the Natural Science Foundation of Gansu province (grant no. 18JR3RA342).

\section{Availability of data and materials}

All data generated or analyzed during this study are included in this published article or are available from the corresponding author on reasonable request.

\section{Authors' contributions}

HL was responsible for the design and implementation of the entire study, and also participated in the acquisition, analysis and writing of all the experimental data. JL participated in the experimental design, and put forward important verification methods for the problems found in the experimental process. JC was involved in the collection and provision of the experimental samples, and participated in the application and implementation of experimental ethics certification. XC was involved in cell experiment technical guidance and assistance. LZ was involved in flow cytometry technical guidance and assistance. ZL was responsible for the design and implementation of the entire study, and participated in the revision of the final version of the manuscript. All authors have read and approved the final manuscript.

\section{Ethics approval and consent to participate}

This study was approved by the Institutional Ethics Committee of the First Hospital of Lanzhou University and written informed consent was obtained from patients and/or their legal guardians.

\section{Patient consent for publication}

Not applicable.

\section{Competing interests}

The authors declare that they have no competing interests.

\section{References}

1. Schofield R: The relationship between the spleen colony-forming cell and the haemopoietic stem cell. Blood Cells 4: 7-25, 1978.

2. Krause DS and Scadden DT: A hostel for the hostile: The bone marrow niche in hematologic neoplasms. Haematologica 100: 1376-1387, 2015

3. Korn C and Méndez-Ferrer S: Myeloid malignancies and the microenvironment. Blood 129: 811-822, 2017.

4. Geyh S, Rodríguez-Paredes M, Jäger P, Khandanpour C, Cadeddu RP, Gutekunst J, Wilk CM, Fenk R, Zilkens C, Hermsen D, et al: Functional inhibition of mesenchymal stromal cells in acute myeloid leukemia. Leukemia 30: 683-691, 2016.

5. Medyouf H: The microenvironment in human myeloid malignancies: Emerging concepts and therapeutic implications. Blood 129: 1617-1626, 2017.

6. Schepers K, Campbell TB and Passegué E: Normal and leukemic stem cell niches: Insights and therapeutic opportunities. Cell Stem Cell 16: 254-267,2015.

7. Kumar A, Anand T, Bhattacharyya J, Sharma A and Jaganathan BG: K562 chronic myeloid leukemia cells modify osteogenic differentiation and gene expression of bone marrow stromal cells. J Cell Commun Signal 12: 441-450, 2018.

8. Battula VL, Le PM, Sun JC, Nguyen K, Yuan B, Zhou X, Sonnylal S, McQueen T, Ruvolo V, Michel KA, et al: AML-induced osteogenic differentiation in mesenchymal stromal cells supports leukemia growth. JCI Insight 2: 90036, 2017.

9. Méndez-Ferrer S, Michurina TV, Ferraro F, Mazloom AR, Macarthur BD, Lira SA, Scadden DT, Ma'ayan A, Enikolopov GN and Frenette PS: Mesenchymal and haematopoietic stem cells form a unique bone marrow niche. Nature 466: 829-834, 2010.

10. Frenette PS, Pinho S, Lucas D and Scheiermann C: Mesenchymal stem cell: Keystone of the hematopoietic stem cell niche and a stepping-stone for regenerative medicine. Annu Rev Immunol 31: 285-316, 2013.

11. Sacchetti B, Funari A, Michienzi S, Di Cesare S, Piersanti S, Saggio I, Tagliafico E, Ferrari S, Robey PG, Riminucci M and Bianco P: Self-renewing osteoprogenitors in bone marrow sinusoids can organize a hematopoietic microenvironment. Cell 131: 324-336, 2007.

12. Song N, Gao L, Qiu H, Huang C, Cheng H, Zhou H, Lv S, Chen L and Wang J: Mouse bone marrow-derived mesenchymal stem cells inhibit leukemia/lymphoma cell proliferation in vitro and in a mouse model of allogeneic bone marrow transplant. Int J Mol Med 36: 139-149, 2015.

13. Zhao Z, Tang X, You Y, Li W, Liu F and Zou P: Assessment of bone marrow mesenchymal stem cell biological characteristics and support hemotopoiesis function in patients with chronic myeloid leukemia. Leuk Res 30: 993-1003, 2006.

14. Huang JC, Basu SK, Zhao X, Chien S, Fang M, Oehler VG, Appelbaum FR and Becker PS: Mesenchymal stromal cells derived from acute myeloid leukemia bone marrow exhibit aberrant cytogenetics and cytokine elaboration. Blood Cancer J 5: e302, 2015.

15. Fracchiolla NS, Fattizzo B and Cortelezzi A: Mesenchymal stem cells in myeloid malignancies: A focus on immune escaping and therapeutic implications. Stem Cells Int 2017: 6720594, 2017.

16. Schroeder T, Geyh S, Germing U and Haas R: Mesenchymal stromal cells in myeloid malignancies. Blood Res 51: 225-232, 2016.

17. Geyh S, Oz S, Cadeddu RP, Fröbel J, Brückner B, Kündgen A, Fenk R, Bruns I, Zilkens C, Hermsen D, Gattermann N, et al: Insufficient stromal support in MDS results from molecular and functional deficits of mesenchymal stromal cells. Leukemia 27: 1841-1851, 2013.

18. von der Heide EK, Neumann M, Vosberg S, James AR, Schroeder MP, Ortiz-Tanchez J, Isaakidis K, Schlee C, Luther M, Jöhrens K, et al: Molecular alterations in bone marrow mesenchymal stromal cells derived from acute myeloid leukemia patients. Leukemia 31: 1069-1078, 2017.

19. Blau O, Hofmann WK, Baldus CD, Thiel G, Serbent V, Schümann E, Thiel E and Blau IW: Chromosomal aberrations in bone marrow mesenchymal stroma cells from patients with myelodysplastic syndrome and acute myeloblastic leukemia. Exp Hematol 35: 221-229, 2007. 
20. Lopes MR, Pereira JK, de Melo Campos P, Machado-Neto JA, Traina F, Saad ST and Favaro P: De novo AML exhibits greater microenvironment dysregulation compared to AML with myelodysplasia-related changes. Sci Rep 7: 40707, 2017.

21. Wang EA, Rosen V, D'Alessandro JS, Bauduy M, Cordes P, Harada T, Israel DI, Hewick RM, Kerns KM, LaPan P, et al: Recombinant human bone morphogenetic protein induces bone formation. Proc Nati Acad Sci USA 87: 2220-2224, 1990.

22. Scarfi S: Use of bone morphogenetic proteins in mesenchymal stem cell stimulation of cartilage and bone repair. World J Stem Cells 8: 1-12, 2016.

23. He Y, Yu L, Liu J, Li Y, Wu Y, Huang Z, Wu D, Wang H, Wu Z and Qiu G: Enhanced osteogenic differentiation of human bone-derived mesenchymal stem cells in 3-dimensional printed porous titanium scaffolds by static magnetic field through up-regulating Smad4. FASEB J 33: 6069-6081, 2019.

24. Zhang Y, Chen B, Li D, Zhou X and Chen Z: LncRNA NEAT1/miR-29b-3p/BMP1 axis promotes osteogenic differentiation in human bone marrow-derived mesenchymal stem cells. Pathol Res Pract 215: 525-531, 2019.

25. Vicente López MA, Vázquez García MN, Entrena A Olmedillas Lopez S, García-Arranz M, García-Olmo D and Zapata A: Low doses of bone morphogenetic protein 4 increase the survival of human adipose-derived stem cells maintaining their stemness and multipotency. Stem Cells Dev 20: 1011-1019, 2011

26. Toofan $\mathrm{P}$ and Wheadon $\mathrm{H}$ : Role of the bone morphogenic protein pathway in developmental haemopoiesis and leukaemogenesis. Biochem Soc Trans 44: 1455-1463, 2016.

27. Zylbersztejn F, Flores-Violante M, Voeltzel T, Nicolini FE, Lefort S and Maguer-Satta V: The BMP pathway: A unique tool to decode the origin and progression of leukemia. Exp Hematol 61: 36-44, 2018.

28. Zhao X, Liu J, Peng M, Liu J and Chen F: BMP4 is involved in the chemoresistance of myeloid leukemia cells through regulating autophagy-apoptosis balance. Cancer Invest 31: 555-562, 2013.

29. Goldman DC, Bailey AS, Pfaffle DL, Al Masri A, Christian JL and Fleming WH: BMP4 regulates the hematopoietic stem cell niche. Blood 114: 4393-4401, 2009.

30. Voeltzel T, Flores-Violante M, Zylbersztejn F, Lefort S, Billandon M, Jeanpierre S, Joly S, Fossard G, Milenkov M, Mazurier F, et al: A new signaling cascade linking BMP4, BMPR1A, DeltaNp73 and NANOG impacts on stem-like human cell properties and patient outcome. Cell Death Dis 9: 1011, 2018.

31. Bradham DM, Igarashi A, Potter RL and Grotendorst GR: Connective tissue growth factor: A cysteine-rich mitogen secreted by human vascular endothelial cells is related to the SRC-induced immediate early gene product CEF10. J Cell Biol 114: 1285-1294, 1991.

32. Aguiar DP, de Farias GC, de Sousa EB, de Mattos CoelhoAguiar J, Lobo JC, Casado PL, Duarte ME and Abreu JG Jr: New strategy to control cell migration and metastasis regulated by CCN2/CTGF. Cancer Cell Int 14: 61, 2014.

33. Jun JI and Lau LF: Taking aim at the extracellular matrix: CCN proteins as emerging therapeutic targets. Nat Rev Drug Discov 10: 945-963, 2011

34. Chen CC and Lau LF: Functions and mechanisms of action of CCN matricellular proteins. Int J Biochem Cell Biol 41: 771-783, 2009.

35. Istvánffy R, Vilne B, Schreck C, Ruf F, Pagel C, Grziwok S, Henkel L, Prazeres da Costa O, Berndt J, Stümpflen V, et al Stroma-derived connective tissue growth factor maintains cell cycle progression and repopulation activity of hematopoietic stem cells in vitro. Stem Cell Rep 5: 702-715, 2015.

36. Mundy C, Gannon M and Popoff SN: Connective tissue growth factor (CTGF/CCN2) negatively regulates BMP-2 induced osteoblast differentiation and signaling. J Cell Physiol 229: 672-681, 2014.

37. Johansen S, Brenner AK, Bartaula-Brevik S, Reikvam $\mathrm{H}$ and Bruserud O: The possible importance of $\beta 3$ integrins for leukemogenesis and chemoresistance in acute myeloid leukemia. Int J Mol Sci 19: E251, 2018.

38. Al-Asadi MG, Brindle G, Castellanos M, May ST, Mills KI, Russell NH, Seedhouse $\mathrm{CH}$ and Pallis $\mathrm{M}$ : A molecular signature of dormancy in CD34+CD38- acute myeloid leukaemia cells. Oncotarget 8: 111405-111418, 2017.

39. Wang J, Liu X, Qiu Y, Shi Y, Cai J, Wang B, Wei X, Ke Q, Sui X, Wang Y, et al: Cell adhesion-mediated mitochondria transfer contributes to mesenchymal stem cell-induced chemoresistance on T cell acute lymphoblastic leukemia cells. J Hematol Oncol 11: $11,2018$.
40. Meads MB, Gatenby RA and Dalton WS: Environment-mediated drug resistance: A major contributor to minimal residual disease. Nat Rev Cancer 9: 665-674, 2009.

41. Winkler IG, Barbier V, Nowlan B, Jacobsen RN, Forristal CE, Patton JT, Magnani JL and Lévesque JP: Vascular niche E-selectin regulates hematopoietic stem cell dormancy, self renewal and chemoresistance. Nat Med 18: 1651-1657, 2012

42. Jacamo R, Chen Y, Wang Z, Ma W, Zhang M, Spaeth EL, Wang Y, Battula VL, Mak PY, Schallmoser K, et al: Reciprocal leukemia-stroma VCAM-1/VLA-4-dependent activation of NF- $\kappa$ B mediates chemoresistance. Blood 123: 2691-2702, 2014.

43. Arber DA, Orazi A, Hasserjian R, Thiele J, Borowitz MJ, Le Beau MM, Bloomfield CD, Cazzola M and Vardiman JW: The 2016 revision to the World Health Organization classification of myeloid neoplasms and acute leukemia. Blood 127: 2391-2405, 2016.

44. World Medical Association: World Medical Association Declaration of Helsinki: Ethical principles for medical research involving human subjects. JAMA 310: 2191-2194, 2013.

45. Nielsen EØ, Chen L, Hansen JO, Degn M, Overgaard S and Ding M: Optimizing Osteogenic differentiation of ovine adipose-derived stem cells by osteogenic induction medium and FGFb, BMP2, or NELL1 in vitro. Stem Cells Int 2018: 9781393 , 2018.

46. Liu X and Harada S: RNA isolation from mammalian samples. Curr Protoc Mol Biol Chapter 4: Unit 4.16, 2013.

47. Livak KJ and Schmittgen TD: Analysis of relative gene expression data using real-time quantitative PCR and the 2(-Delta Delta C(T)) method. Methods 25: 402-408, 2001

48. Zor T and Selinger Z: Linearization of the Bradford protein assay increases its sensitivity: Theoretical and experimental studies. Anal Biochem 236: 302-308, 1996.

49. Dominici M, Le Blanc K, Mueller I, Slaper-Cortenbach I, Marini F, Krause D, Deans R, Keating A, Prockop Dj and Horwitz E: Minimal criteria for defining multipotent mesenchymal stromal cells. The International Society for cellular therapy position statement. Cytotherapy 8: 315-317, 2006.

50. Gribble SM, Roberts I, Grace C, Andrews KM, Green AR and Nacheva EP: Cytogenetics of the chronic myeloid leukemia-derived cell line K562: Karyotype clarification by multicolor fluorescence in situ hybridization, comparative genomic hybridization, and locus-specific fluorescence in situ hybridization. Cancer Genet Cytogenet 118: 1-8, 2000.

51. Kouvidi E, Stratigi A, Batsali A, Mavroudi I, Mastrodemou S, Ximeri M, Papadaki HA and Pontikoglou CG: Cytogenetic evaluation of mesenchymal stem/stromal cells from patients with myelodysplastic syndromes at different time-points during ex vivo expansion. Leuk Res 43: 24-32, 2016.

52. Blau O, Baldus CD, Hofmann WK, Thiel G, Nolte F, Burmeister T, Türkmen S, Benlasfer O, Schümann $\mathrm{E}$, Sindram A, et al: Mesenchymal stromal cells of myelodysplastic syndrome and acute myeloid leukemia patients have distinct genetic abnormalities compared with leukemic blasts. Blood 118: 5583-5592, 2011

53. Soenen-Cornu V, Tourino C, Bonnet ML, Guillier M, Flamant S, Kotb R, Bernheim A, Bourhis JH, Preudhomme C, Fenaux P and Turhan AG: Mesenchymal cells generated from patients with myelodysplastic syndromes are devoid of chromosomal clonal markers and support short- and long-term hematopoiesis in vitro. Oncogene 24: 2441-2448, 2005.

54. Jootar S, Pornprasertsud N, Petvises S, Rerkamnuaychoke B, Disthabanchong S, Pakakasama S, Ungkanont A and Hongeng S: Bone marrow derived mesenchymal stem cells from chronic myeloid leukemia $\mathrm{t}(9 ; 22)$ patients are devoid of Philadelphia chromosome and support cord blood stem cell expansion. Leuk Res 30: 1493-1498, 2006.

55. Flores-Figueroa E, Montesinos JJ, Flores-Guzmán P, Gutiérrez-Espíndola G, Arana-Trejo RM, Castillo-Medina S, Pérez-Cabrera A, Hernández-Estévez E, Arriaga L and Mayani H: Functional analysis of myelodysplastic syndromes-derived mesenchymal stem cells. Leuk Res 32: 1407-1416, 2008.

56. Aanei CM, Flandrin P, Eloae FZ, Carasevici E, Guyotat D, Wattel E and Campos L: Intrinsic growth deficiencies of mesenchymal stromal cells in myelodysplastic syndromes. Stem Cells Dev 21: 1604-1615, 2012.

57. Chandran P, Le Y, Li Y, Sabloff M, Mehic J, Rosu-Myles M and Allan DS: Mesenchymal stromal cells from patients with acute myeloid leukemia have altered capacity to expand differentiated hematopoietic progenitors. Leuk Res 39: 486-493, 2015 
58. Reikvam H, Brenner AK, Hagen KM, Liseth K, Skrede S, Hatfield KJ and Bruserud Ø: The cytokine-mediated crosstalk between primary human acute myeloid cells and mesenchymal stem cells alters the local cytokine network and the global gene expression profile of the mesenchymal cells. Stem Cell Res 15: 530-541, 2015.

59. Mohammadi S, Nikbakht M, Sajjadi SM, Rad F, Chahardouli B, Sabour Takanlu J,Rostami Sh, Alimoghaddam K, Ghavamzadeh A and Ghaffari SH: Reciprocal interactions of leukemic cells with bone marrow stromal cells promote enrichment of leukemic stem cell compartments in response to curcumin and daunorubicin. Asian Pac J Cancer Prev 18: 831-840, 2017.

60. BeckerPS: Dependence of acute myeloid leukemia on adhesion within the bone marrow microenvironment. ScientificWorldJournal 2012: $856467,2012$.

61. Konopleva M, Konoplev S, Hu W, Zaritskey AY, Afanasiev BV and Andreeff M: Stromal cells prevent apoptosis of AML cells by up-regulation of anti-apoptotic proteins. Leukemia 16 1713-1724, 2002.

62. Nwajei F and Konopleva M: The bone marrow microenvironment as niche retreats for hematopoietic and leukemic stem cells. Adv Hematol 2013: 953982, 2013.

63. Damiano JS, Hazlehurst LA and Dalton W: Cell adhesion-mediated drug resistance (CAM-DR) protects the K562 chronic myelogenous leukemia cell line from apoptosis induced by BCR/ABL inhibition, cytotoxic drugs, and gamma-irradiation. Leukemia 15: 1232-1239, 2001.

64. Aguiar DP, Coelho-Aguiar JM and Abreu JG: CCN2/CTGF silencing blocks cell aggregation in embryonal carcinoma P19 cell. Braz J Med Biol Res 44: 200-205, 2011.

65. Kumar A, Bhattacharyya J and Jaganathan BG: Adhesion to stromal cells mediates imatinib resistance in chronic myeloid leukemia through ERK and BMP signaling pathways. Sci Rep 7: 9535, 2017.

66. Kojima K, McQueen T, Chen Y, Jacamo R, Konopleva M, Shinojima N, Shpall E, Huang X and Andreeff M: p53 activation of mesenchymal stromal cells partially abrogates microenvironment-mediated resistance to FLT3 inhibition in AML through HIF-1 $\alpha$-mediated down-regulation of CXCL12. Blood 118 4431-4439, 2011.
67. Naugler WE and Karin M: The wolf in sheep's clothing: The role of interleukin-6 in immunity, inflammation and cancer. Trends Mol Med 14: 109-119, 2008.

68. Rose-John S: IL-6 trans-signaling via the soluble IL-6 receptor: Importance for the pro-inflammatory activities of IL-6. Int J Biol Sci 8: 1237-1247, 2012.

69. Fisher DT, Chen Q, Skitzki JJ, Muhitch JB, Zhou L, Appenheimer MM, Vardam TD, Weis EL, Passanese J, Wang WC, et al: IL-6 trans-signaling licenses mouse and human tumor microvascular gateways for trafficking of cytotoxic T cells. J Clin Invest 121: 3846-3859, 2011.

70. Onishi $\mathrm{K}$ and Zandstra PW: LIF signaling in stem cells and development. Development 142: 2230-2236, 2015.

71. Itoh $F$, Watabe $T$ and Miyazono K: Roles of TGF- $\beta$ family signals in the fate determination of pluripotent stem cells. Semin Cell Dev Biol 32: 98-106, 2014.

72. Conze D, Weiss L, Regen PS, Bhushan A, Weaver D, Johnson P and Rincón M: Autocrine production of interleukin 6 causes multidrug resistance in breast cancer cells. Cancer Res 61: 8851-8858, 2001

73. Desbourdes L, Javary J, Charbonnier T, Ishac N, Bourgeais J, Iltis A, Chomel JC, Turhan A, Guilloton F, Tarte K, et al: Alteration analysis of bone marrow mesenchymal stromal cells from de novo acute myeloid leukemia patients at diagnosis. Stem Cells Dev 26: 709-722, 2017.

74. Pontikoglou C, Kastrinaki MC, Klaus M, Kalpadakis C, Katonis P, Alpantaki K, Pangalis GA and Papadaki HA: Study of the quantitative, functional, cytogenetic, and immunoregulatory properties of bone marrow mesenchymal stem cells in patients with B-cell chronic lymphocytic leukemia. Stem Cells Dev 22: 1329-1341, 2013.

75. Ogden A, Rida PC, Knudsen BS, Kucuk O and Aneja R: Docetaxel-induced polyploidization may underlie chemoresistance and disease relapse. Cancer Lett 367: 89-92, 2015.

This work is licensed under a Creative Commons

Attribution-NonCommercial-NoDerivatives 4.0 International (CC BY-NC-ND 4.0) License. 